\title{
EFFECT OF NOISE AND PIXEL SIZE ON THE WAVEFRONT GENERATED BY AMPLITUDE HOLOGRAMS
}

\author{
A. A. Goloborodko ${ }^{1,2}$ \\ ${ }^{1}$ OpenSoft LTD, 1, Chornomorska St., office 301, Kyiv, UA-04655, Ukraine, \\ ${ }^{2}$ Taras Shevchenko National University of Kyiv, \\ 64/13, Volodymyrska St., Kyiv, UA-01601, Ukraine \\ e-mail: a.a.goloborodko@gmail.com
}

(Received 06 February, 2019; in final form 01 July, 2019)

\begin{abstract}
The possibilities of wavefront generation by amplitude holograms are theoretically and experimentally investigated. Holograms could be generated in any PC using a MATLAB program developed by the author. The wavefronts of the generated holograms are obtained experimentally and confirmed by theoretical calculations both qualitatively and quantitatively. The errors of wavefront restoration are obtained on the example of the first 12 Zernike aberrations. The effect of the pixel size and pixelate noise on hartmanogramms of the generated wavefront and restored wavefronts are experimentally investigated.
\end{abstract}

Key words: wavefront sensing, adaptive optics, aberration measurements, error analysis.

DOI: https://doi.org/10.30970/jps.23.4401

PACS number(s): 42.15.Dp, 42.40.Jv, 42.15.Fr

\section{INTRODUCTION}

The generation of optical wavefronts, their perturbation and subsequent acquisition within a controlled environment such as an optical laboratory setup is an important problem of modern adaptive optics [1,2]. The ability to control the dynamics of temporally evolving perturbations is essential for the measurements of the eyesight aberrations [3], for turbulence compensation in astronomy [4], in optical defectoscopy [5], and elsewhere. Computationally, closed-loop systems $[6]$ are comparatively less stringent since they are produced on the basis of electromechanical controls that correct the optical path in real-time. The mentioned system needs a reference phase screen, which can be generated using a computer program as a $2 \mathrm{D}$ array of phase distortions and has the same set of aberrations as injected by the optical channel. However, according to [7], the image calibration of any optical system could be done using amplitude holograms to avoid the phase component. Therefore, the present paper is devoted to the study of efficient algorithms used for the estimating and correction of aberrations of different optical systems. The development of the amplitude diffractive optical element (DOE), described in the paper, is the easiest way to correct aberrations of an optical system and could be used directly in the image plane or introduced indirectly by using the interference of the corrected wave and the image one.

The layout of the paper is as follows. The optical setup developed for this study is given in Section II. A brief background on optical setups, emphasizing the use of diffractive optical elements to generate phase aberrations, is given in Section III, which includes an overview of wavefront propagation and DOE generation. The experimental results of image restoration using the direct wavefront sensing and discussion are given in Section IV. Finally, some concluding remarks are made in Section V.

\section{EXPERIMENTAL SETUP}

The optical setup configuration is shown in Fig. 1.

The basic configuration comprising a $\mathrm{He}-\mathrm{Ne}$ laser module, supporting the polarized $30 \mathrm{~mW}$ source at 632.8 $\mathrm{nm}$, is shown at the top of the figure. Mirror M1 and lenses L1, L2 create the plane wavefront for the propagation via movable mirrors and mirror M3 (reference channel), or via mirror M2, DOE to form an aberrated wavefront. The DOE with the compensation of the carrier spatial frequency is used to introduce wavefront phase aberrations (MATLAB code, depicted in [10], is used to create DOE profile). As one knows [11], a beamsplitter could be used for the wavefront correction in an indirect way, however additional calculation of the DOE image is needed. Lenses L4, L5 or L3, L5 are configured for a $4 \mathrm{~F}$ system, where imaging is performed by the holographic Shack-Hartmann wavefront sensor [8,9]. The point spread function (PSF) of the aberrated wavefronts analysis and verification is allowed in the second channel containing beamsplitter BS, lens L7 and CCD2. Two cameras KPC-303BH manufactured by KT\&C are used. This camera supported a 8-bit grayscale Sony image sensor, providing good resolution and high-speed performance for capturing video sequences.

The PSFs of a plane wavefront are shown in Fig. 2, where the reference PSF in the channel with mirror M3 is compared with the one from the channel with mirror M2 (Fig. 2c). As one can see, the used tilt of $0.5^{\circ}$ does only cause image displacement, and no increas in the PSF size caused by the tilt is observed [12]. 


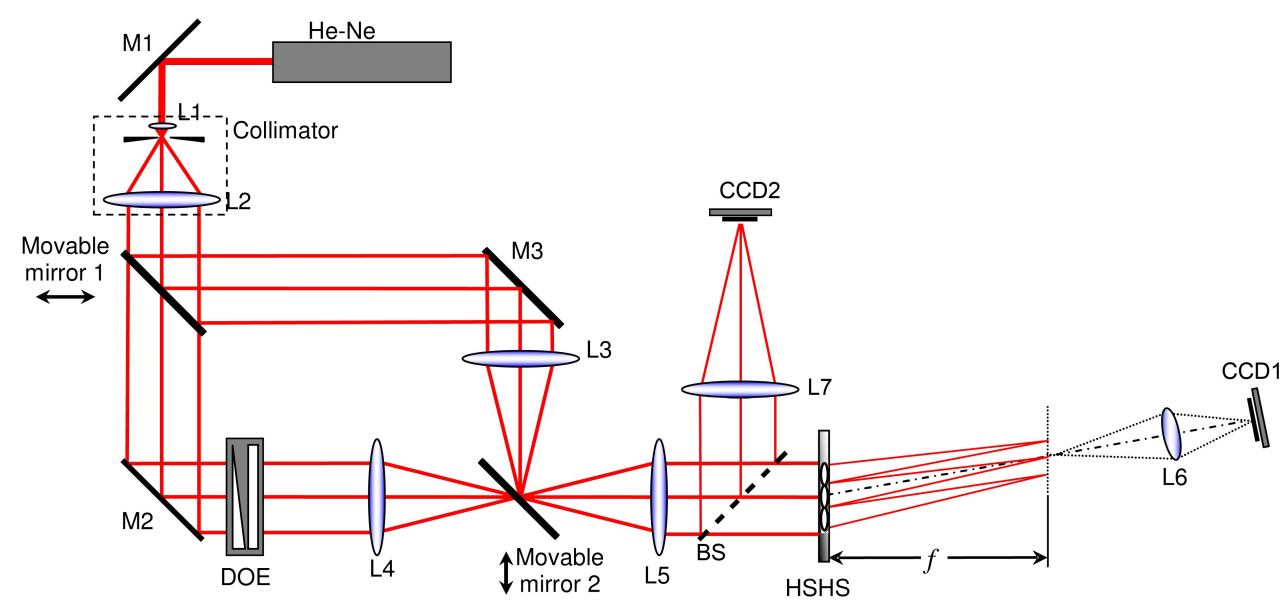

Fig. 1. Basic configuration of experimental setup. Source $(632.8 \mathrm{~nm})$ He-Ne laser with polarizing filter, mirror M1 with a collimator (lens assembly L1 and L2), movable mirrors and mirror M3 are used to generate a plane reference wavefront for calibration. Mirror M2 and DOE with the compensation of carrier spatial frequency are used to generate an aberrated wavefront. Wavefront sensor module comprises a holographic Shack-Hartmann sensor (HSHS) as in [8].

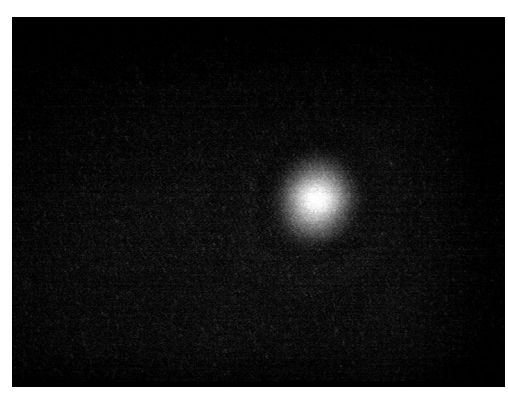

(a)

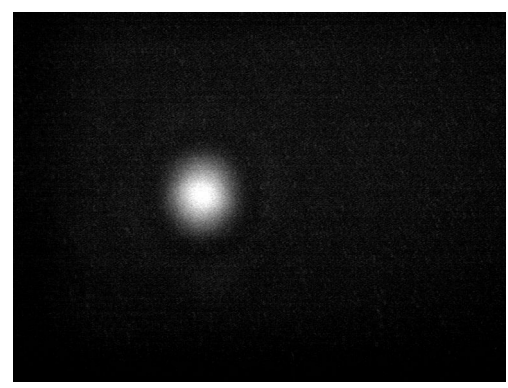

(b)

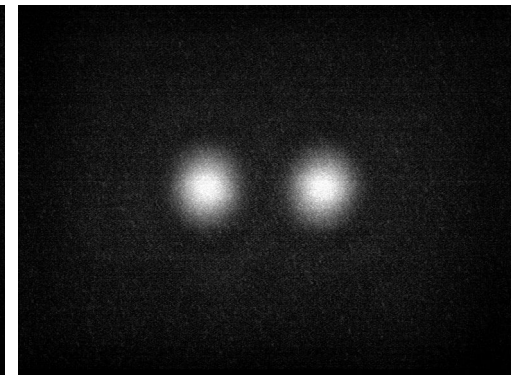

(c)

Fig. 2. Point spread functions for the mirror reference (a), the DOE reference (b), and the computer generated sum of two channels (c).

\section{THEORY AND SIMULATION}

Any optical system input and output can be related by the simple equation [12]:

$$
U(x, y \mid z)=\int_{-\infty}^{\infty} \int_{-\infty}^{\infty} U(\xi, \eta \mid 0) \operatorname{OTF}(x-\xi, y-\eta \mid z) d \xi d \eta,
$$

where $U(\xi, \eta \mid 0)$ is the initial amplitude of the wave, OTF is the small angle approximation of the free space optical transfer function $[13,14]$ :

$$
\operatorname{OTF}(x-\xi, y-\eta \mid z)=\frac{1}{i \lambda z} e^{i \frac{2 \pi z}{\lambda}} e^{i \frac{\pi}{\lambda z}\left((x-\xi)^{2}+(y-\eta)^{2}\right)},
$$

where $\lambda$ is wavelength, $z$ is the distance from DOE to the image plane. The fundamental expression (1) demonstrates the important fact that any linear system is completely characterized by its responses to unit signals. However, PSF is used to provide knowledge a posteriori of the angular effect of anisoplanatism [1]. Considering the distance of the propagation of the light pupil from lens L7 to image plane $z$, additional phase shifts on lens L7, the relationship between the wavefront and PSF is given by Goodman [12]:

$$
\operatorname{PSF}(x, y \mid z)=\left|\hat{\mathrm{F}}_{U}(x, y \mid z)\right|^{2}=\left|e^{-i 2 \pi \frac{z}{\lambda}} \int_{-a / 2}^{a / 2} \int_{-a / 2}^{a / 2} U(\xi, \eta \mid 0) e^{-i \frac{2 \pi}{\lambda z}(x \xi+y \eta)} d \xi d \eta\right|^{2} \equiv \operatorname{PSF}(x, y),
$$


where $a$ is the pupil aperture (image lateral dimension), $\hat{\mathrm{F}}_{U}(x, y \mid z)$ is the Fourier transform of $U(\xi, \eta \mid 0)$.

Initial amplitude $U(\xi, \eta \mid 0)$ is determined by the DOE as $U(\xi, \eta \mid 0)=U_{0} T(\xi, \eta)$, where the transmittance function of the DOE in terms of two waves can be expressed as:

$$
T(\xi, \eta)=T_{0} \frac{\left|e^{i \phi(\xi, \eta)}+1\right|^{2}}{2},
$$

where $T_{0}=1$ is general transmittance (weighting function), $\phi(x, y)$ is the aberrated wavefront which should be generated. One should note that according to [12], coefficient $\frac{1}{2}$ in (4) could be neglected to get identical total beam amplitudes on the input and output of DOE, however in the present paper this coefficient is neglected only for the PSF image calculation. Zernike polynomials $Z_{m}^{n}$ are used to perform controlled aberrations [15]:

$$
\phi(\xi, \eta)=\pi \sum_{n, m} \alpha_{m}^{n} Z_{m}^{n},
$$

where $\alpha_{m}^{n}$ denotes the Zernike amplitudes or coefficients. The present paper deals exclusively with the first four aberration orders: astigmatism $\left(Z_{2}^{-2}\right.$ and $\left.Z_{2}^{2}\right)$, defocus $\left(Z_{2}^{0}\right)$, trefoil $\left(Z_{3}^{-3}\right.$ and $\left.Z_{3}^{3}\right)$, coma $\left(Z_{3}^{-1}\right.$ and $\left.Z_{3}^{1}\right)$, quadrafoil $\left(Z_{4}^{-4}\right.$ and $\left.Z_{4}^{4}\right)$, secondary astigmatism $\left(Z_{4}^{-2}\right.$ and $\left.Z_{4}^{2}\right)$, and primary spherical $\left(Z_{4}^{0}\right)$. As one knows, some literature uses different index schemes [13,15-17]. Therefore, care should be taken when comparing results from different journal papers and software packages, due to the variety of indexing schemes that are available. So present the paper deals with the scheme depicted in [15]. Fig. 3 shows the holograms of aberrated waves.

To avoid an interference of diffraction orders, a small tilt should be used, and the transmittance function of the DOE can be defined as:

$$
T(\xi, \eta)=\frac{\left|e^{i \phi(\xi, \eta)+i \frac{2 \pi}{\lambda} \xi \sin \psi}+1\right|^{2}}{2}
$$

where $\psi$ is the tilt angle. One should note that for an additional tilt Zernike polynomials $Z_{1}^{-1}$ and $Z_{1}^{1}$ could be used [15]. Fig. 4 shows the holograms of an aberrated wavefront with the additional tilt of $0.5^{\circ}$.

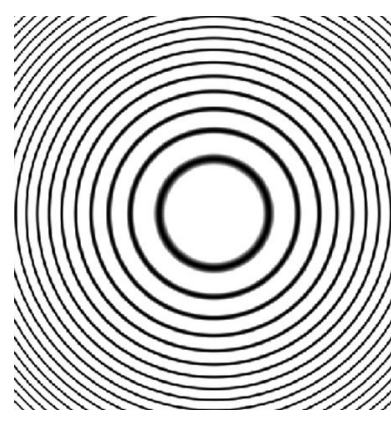

(a)

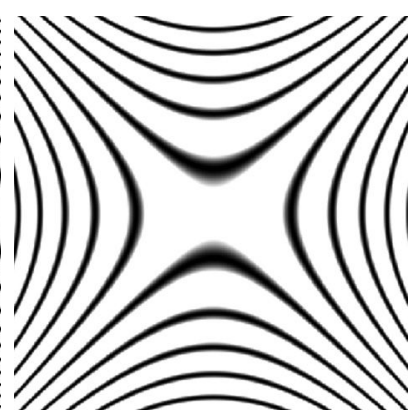

(b)

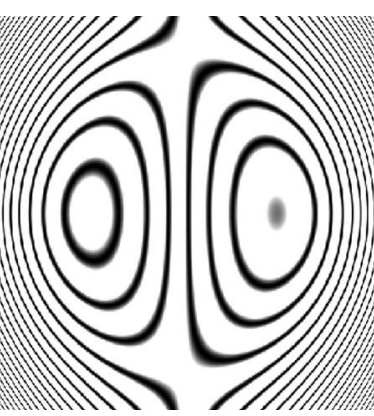

(c)

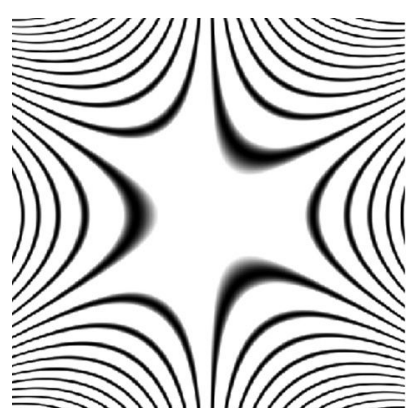

(d)

Fig. 3. Sample of defocus (a), astigmatism (b), coma (c) and trefoil (d) holograms. Parameters are $R=5 \mathrm{~mm}$, $\alpha_{2}^{0}=\alpha_{2}^{2}=\alpha_{3}^{1}=\alpha_{3}^{3}=5$.

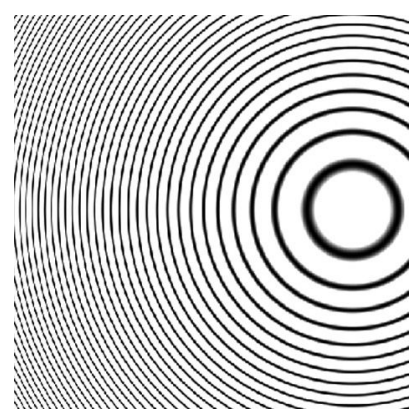

(a)

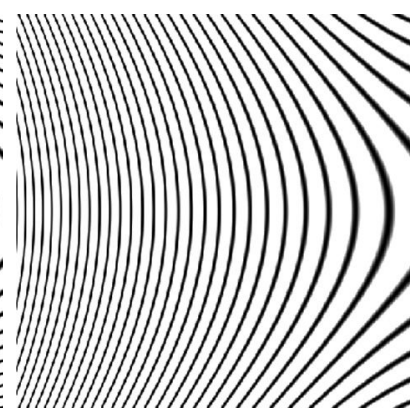

(b)

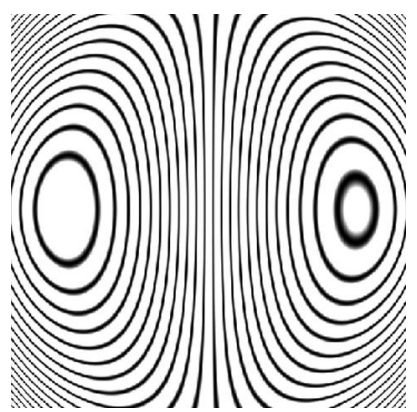

(c)

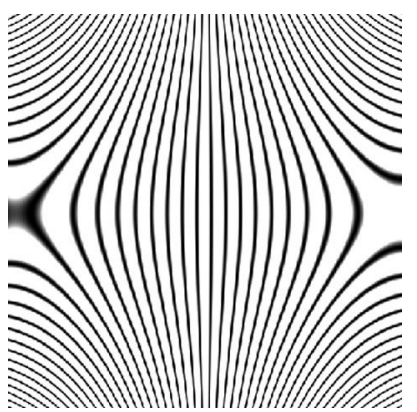

(d)

Fig. 4. Same as on Fig. 3, but with the additional tilt $\psi=0.5^{\circ}$.

One can see the interference lines with the structure close to the one on fig. 3. Additional vertical lines denote the small tilt which was used for the generation.

With respect of the experimental setup, PSF is determined by the DOE with the tilt compensation and the focal length of lens L7 $\left(z=f_{\mathrm{L} 7}\right)$ :

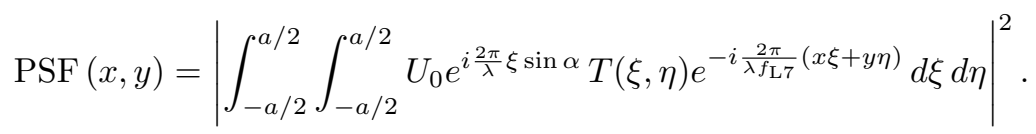




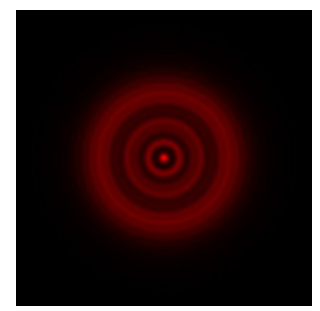

(a)

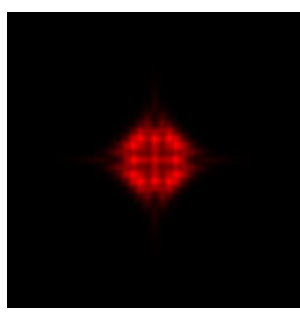

(b)

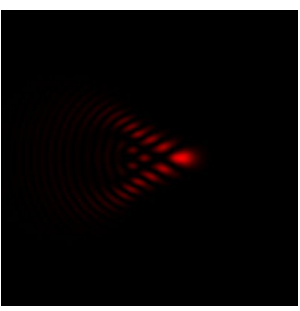

(c)

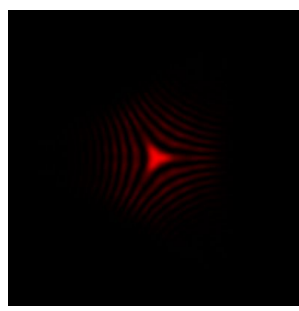

(d)

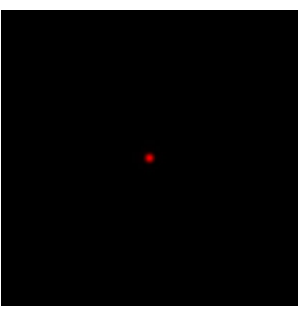

(e)

Fig. 5. PSF for the aberrated wavefronts: defocus (a), astigmatism (b), coma (c) and trefoil (d), depicted on Fig. 3. For comparison, (e) shows the PSF of a spatially limited optical system [13].

Figure 5 shows the PSFs calculated using amplitude DOEs from Fig. 4 spatial distributions. It is visible that PSF images are close to the ones from the literature $[13,18,19]$. Additional aberration images are visible on the holograms (Fig. 4) due to the image resolution in paper, however, these images PSFs and restored wavefronts. The examination of the generated DOEs on the wavefront reconstruction and error estimations is made in the next Section.

\section{EXPERIMENTAL RESULTS AND DISCUSSION}

\section{A. Wavefront generation and calibration}

Employing the above algorithm, the wavefronts of the first 12 polynomials were generated, which cover the first four orders of the Zernike polynomials. Using the program described in [10] the values of the required inputs (aperture parameters, pixel size, the light wavelength, the pupil angles and the Zernike amplitudes) are inputted via a graphic user interface into the program.
Holograms with lateral step $\approx 7 \mu \mathrm{m}$ are generated to test the optical system and calibration. The obtained DOEs were inserted in the experimental setup together with the compensation of the carrier spatial frequency (see Fig. 1).

The Zernike coefficients of the aberrations that contribute to the wavefront distortions were determined, using the procedure described in [20]. Table shows the restored Zernike coefficients for the holograms with the recorded aberrations with $\alpha_{n}^{m}=5$. As is shown in Table, for each generated wavefront the restored coefficients are close to the target value of 5 and all other coefficients are close to zero.

The record-recovery error was estimated using the restored Zernike coefficients for each hologram with aberrations up to the fourth order. As one can see, the error does not exceed $3.2 \%$, and differences in the values are caused by the error that occurs due to the imperfect manufacturing process and possible infiltration of dust particles, which affects under such microscopic parameters of the DOEs. However, this error can be further minimized by improving the process of recording of the amplitude diffraction element or by using spatial light modulator.

\begin{tabular}{|c|c|c|c|c|c|c|c|}
\hline \multicolumn{4}{|l|}{ Restored } & \multicolumn{4}{|l|}{ Recorded } \\
\hline No $\quad \alpha$ & $\alpha_{2}^{0}$ & $\alpha_{2}^{2}$ & $\alpha_{3}^{1}$ & $\alpha_{3}^{3}$ & $\alpha_{4}^{0}$ & $\alpha_{4}^{2}$ & $\alpha_{4}^{4}$ \\
\hline $1 \alpha_{2}^{-2}$ & $1.44 \cdot 10^{-3}$ & $3.56 \cdot 10^{-2}$ & $1.28 \cdot 10^{-2}$ & $-2.34 \cdot 10^{-3}$ & $-2.89 \cdot 10^{-2}$ & $-6.55 \cdot 10^{-3}$ & $8.78 \cdot 10^{-3}$ \\
\hline$\alpha_{2}^{0}$ & 4.89 & $1.13 \cdot 10^{-2}$ & $9.63 \cdot 10^{-3}$ & $7.89 \cdot 10^{-3}$ & $-5.21 \cdot 10^{-2}$ & $4.25 \cdot 10^{-3}$ & $5.63 \cdot 10^{-3}$ \\
\hline$\alpha_{2}^{2}$ & $-1.98 \cdot 10^{-3}$ & 5.13 & $-1.02 \cdot 10^{-3}$ & $7.58 \cdot 10^{-3}$ & $7.44 \cdot 10^{-3}$ & $-9.84 \cdot 10^{-2}$ & $1.56 \cdot 10^{-3}$ \\
\hline $4 \alpha_{3}^{-3}$ & $-1.21 \cdot 10^{-2}$ & $2.23 \cdot 10^{-2}$ & $-6.12 \cdot 10^{-3}$ & $1.54 \cdot 10^{-2}$ & $3.14 \cdot 10^{-2}$ & $-2.08 \cdot 10^{-2}$ & $-3.97 \cdot 10^{-3}$ \\
\hline$\alpha_{3}^{-1}$ & $3.27 \cdot 10^{-2}$ & $-3.69 \cdot 10^{-2}$ & $-1.23 \cdot 10^{-2}$ & $5.16 \cdot 10^{-3}$ & $-2.12 \cdot 10^{-2}$ & $-4.54 \cdot 10^{-3}$ & $2.62 \cdot 10^{-2}$ \\
\hline$\alpha_{3}^{1}$ & $1.86 \cdot 10^{-2}$ & $2.57 \cdot 10^{-3}$ & 4.84 & $-1.95 \cdot 10^{-3}$ & $-3.79 \cdot 10^{-4}$ & $-6.13 \cdot 10^{-3}$ & $9.45 \cdot 10^{-4}$ \\
\hline$\alpha_{3}^{3}$ & $-2.33 \cdot 10^{-2}$ & $-7.85 \cdot 10^{-3}$ & $5.47 \cdot 10^{-3}$ & 5.14 & $6.13 \cdot 10^{-3}$ & $9.45 \cdot 10^{-4}$ & $5.98 \cdot 10^{-4}$ \\
\hline$\alpha_{4}^{-4}$ & $1.57 \cdot 10^{-3}$ & $-3.33 \cdot 10^{-2}$ & $-8.56 \cdot 10^{-3}$ & $4.12 \cdot 10^{-2}$ & $1.14 \cdot 10^{-2}$ & $-9.51 \cdot 10^{-3}$ & $4.15 \cdot 10^{-3}$ \\
\hline$\alpha_{4}^{-2}$ & $-1.19 \cdot 10^{-3}$ & $-7.79 \cdot 10^{-3}$ & $-5.31 \cdot 10^{-3}$ & $9.44 \cdot 10^{-3}$ & $1.75 \cdot 10^{-2}$ & $-1.88 \cdot 10^{-2}$ & $-3.64 \cdot 10^{-2}$ \\
\hline$\alpha_{4}^{0}$ & $9.45 \cdot 10^{-4}$ & $1.86 \cdot 10^{-2}$ & $2.57 \cdot 10^{-3}$ & $-1.25 \cdot 10^{-2}$ & 4.86 & $-3.79 \cdot 10^{-4}$ & $-6.13 \cdot 10^{-3}$ \\
\hline$\alpha_{4}^{2}$ & $-7.97 \cdot 10^{-4}$ & $1.94 \cdot 10^{-2}$ & $2.34 \cdot 10^{-3}$ & $-3.29 \cdot 10^{-2}$ & $7.56 \cdot 10^{-4}$ & 4.86 & $-7.85 \cdot 10^{-2}$ \\
\hline $12 \quad \alpha_{4}^{4}$ & $-1.54 \cdot 10^{-2}$ & $-1.35 \cdot 10^{-2}$ & $5.67 \cdot 10^{-3}$ & $7.89 \cdot 10^{-4}$ & $-8.15 \cdot 10^{-3}$ & $-1.57 \cdot 10^{-2}$ & 5.14 \\
\hline Error, \% & 2.1 & 2.6 & 3.2 & 2.8 & 2.9 & 2.9 & 2.8 \\
\hline
\end{tabular}

Table. Zernike coefficients for the produced diffractive optical elements. 
One should note that the usage of phase screens is complicated by phase deviations in the screen. The deviations are lightly controlled with the usage of spatial light modulators [21], however, they are not completely controlled in the case of using PFG-01 holographic plates [22]. Phase errors cause additional phase noise, which leads to the speckles in the Shack-Hartman sensor im- age plane [12]. High spatial frequencies of the phase noise (a small amount of noise pixels) could be filtered by using lenses L4 and L5 [23]. However, the present paper does not deal with noise filtering and the effect of unfiltered noise on the wavefront restoration can be found in the next Subsection.

\section{B. Noise effect}

With the idea of observing the performance of a more realistic situation a number of DOEs were produced as the later wavefront with a noise signal [24]. Fig. 6 shows the holograms with different pixelate noise [25, 26]. The coefficients measured from the generated holograms are shown in Fig. 7.

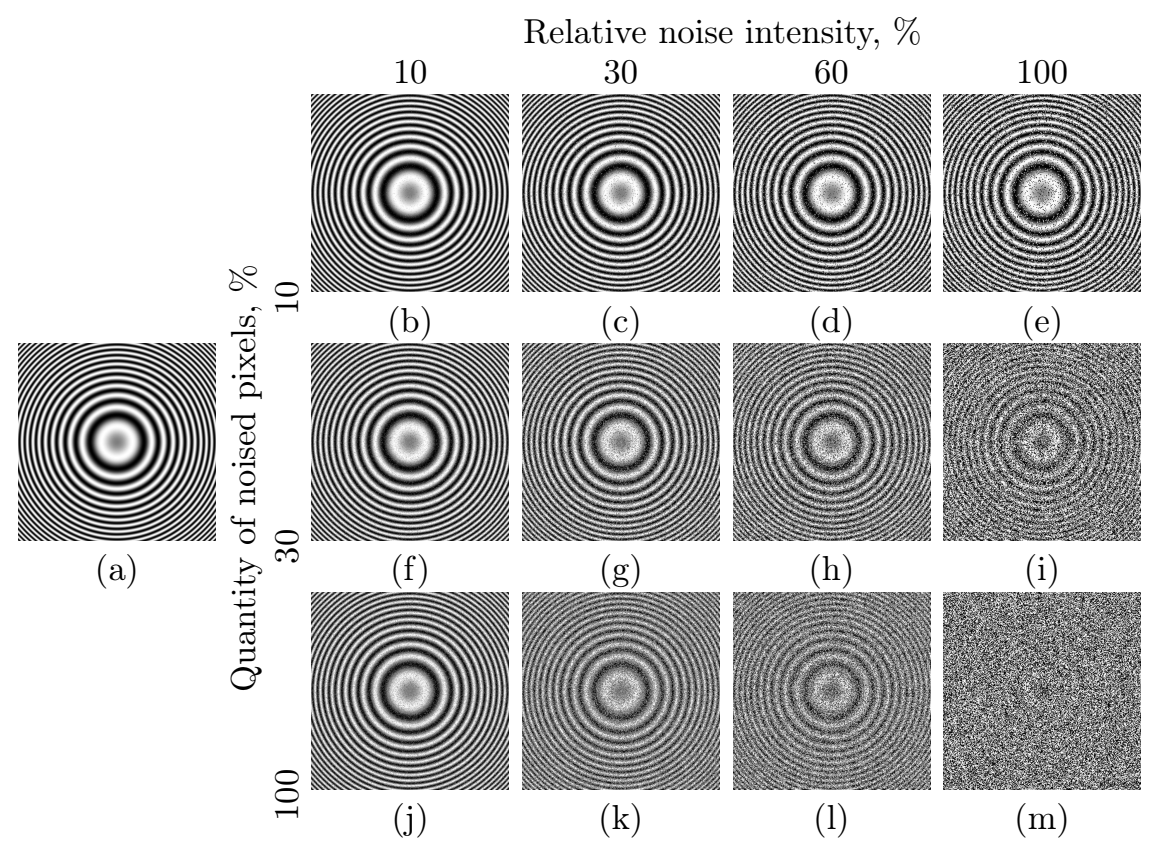

Fig. 6. Holograms of defocus $\alpha_{2}^{0}=5$ without noise (a), with noise (b)-(m).

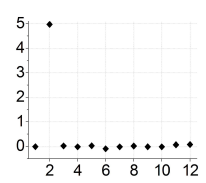

(b)

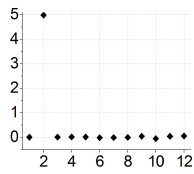

(a)

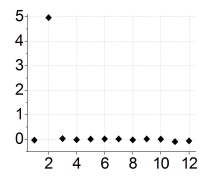

(f)

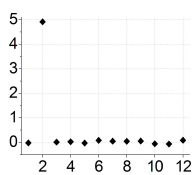

(c)

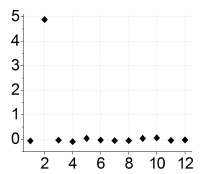

(j)

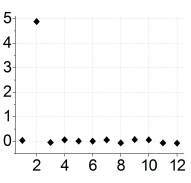

(g)

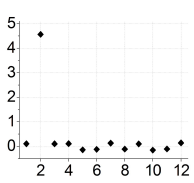

$(\mathrm{k})$

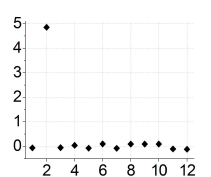

(d)

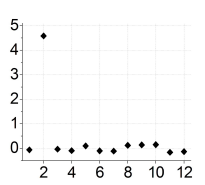

(h)

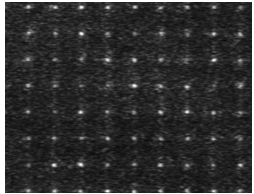

(1)

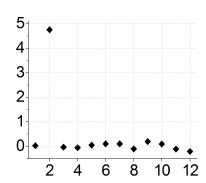

(e)

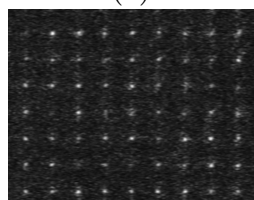

(i)

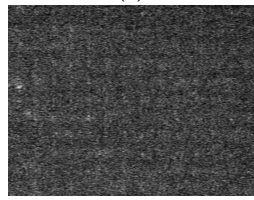

$(\mathrm{m})$

Fig. 7. Measured Zernike coefficients for the holograms from Fig. 6 without noise (a), with noise (b)-(h), (j), (k). Speckle patterns in Shack-Hartmann wavefront sensor (i), (l), (m). 


\section{A. A. GOLOBORODKO}

As one can see, even in the presence of a high level noise (Fig. 6) the Zernike coefficients of the DOE could be measured (Fig. 7). On the other hand, it can be also observed, that an increase in the noise intensity leads to an increase in the amplitude of higher modes (Fig. 7), at the same time the variation of the coefficient increases too $[13,23]$.

One can see the light spots from the DOEs (i) and (1) on Fig. 6. However, used centroid computation algorithms $[27,28]$ cannot find the centre of spots. The last $\operatorname{DOE}(\mathrm{m})$ on Fig. 6 forms only an irregular speckle structure.

\section{Pixel size effect}

To verify the stability of the DOEs to the pixel size (this allows using the amplitude or the phase spatial light modulator (SLM), like in [29], for wavefront generation), a number of holograms were produced witha different step. Fig. 8 shows the error for the used 12 Zernike polynomials. One can see that the pixel size does not exceed $50 \mu \mathrm{m}$, the percentage error is less than $5 \%$.

Despite the LCD dimensions, which are normally larger than the dimension of the CCD, the usage of SLM with the step less than $50 \mu \mathrm{m}$ does not introduce large errors in the optical wavefront. Besides, the usage of an optical beam compressor [29], which can introduce additional aberrations, is not necessary.

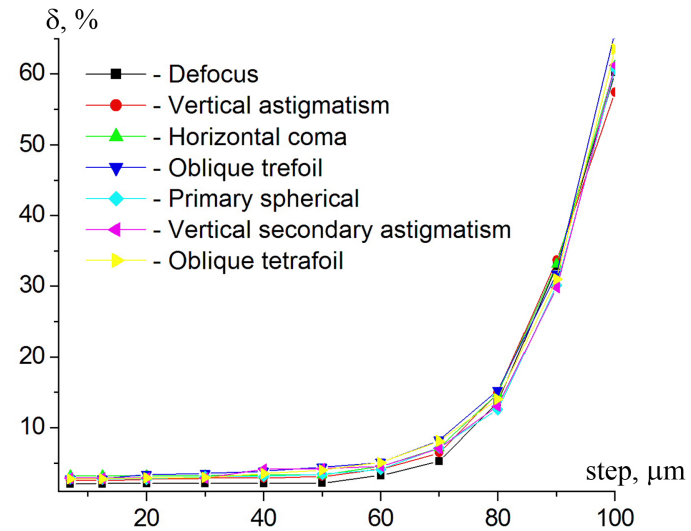

Fig. 8. Mean error via step size for the produced DOEs.

\section{CONCLUDING REMARKS}

The wavefronts of the first 12 Zernike modes were generated, using produced holograms with arbitrary aberrations and the experimental setup depicted in Section II. The results show that lower-order wavefront modes can be generated with high accuracy (error does not exceed $5 \%$ ) in a large dynamic range (Zernike coefficients are up to 5). The experimental results show that the maximal lateral pixel step size should not exceed $50 \mu \mathrm{m}$. It was shown that the generated holograms are stable enough to the pixelate noise on the plate.
[1] J. W. Hardy, Adaptive Optics for Astronomical Telescopes (Oxford University Press, Oxford, 1998).

[2] R. Davies, M. Kasper, Ann. Rev. Astron. Astrophys. 50, 305 (2012); https://doi.org/10.1146/ annurev-astro-081811-125447.

[3] S. Manzanera, C. Canovas, P. M. Prieto, P. Artal, Opt. Express 16, 7748 (2008); https://doi.org/10.1364/ OE. 16.007748.

[4] V. P. Lukin, L. A. Bol'basova, J. Phys. Conf. Ser. 1096 , 012121 (2018); https://doi.org/10.1088/1742-6596/ 1096/1/012121.

[5] V. Buchenko, A. Goloborodko, V. Lendel, O. Oberemok, J. Nano- Electron. Phys. 7, 03023 (2014).

[6] Adaptive Optics for Astronomy, edited by D. Alloin, J.-M. Mariotti (KluwerAcademic Publishers, 1994).

[7] S. A. Benton, V. M. Bove, Holographic Imaging (John Wiley \& Sons, Inc., 2008).

[8] J.-Y. Son, D. Podanchuk, V. Dan'ko, K.-D. Kwak, Opt. Eng. 42, 3389 (2003); https://doi.org/10.1117/1. 1614264.

[9] D. Podanchuk, A. Goloborodko, M. Kotov, D. Petriv, Ukr. J. Phys. 60, 10 (2015); https://doi.org/10. 15407/ujpe60.01.0010.

[10] A. A. Goloborodko, DOE generator (Matlab project) (2018); https://doi.org/10.13140/RG.2.2.33717.37609.

[11] S. Weddell, A. Lambert, Appl. Opt. 53, 8205 (2014); https://doi.org/10.1364/A0.53.008205.
[12] J. W. Goodman, Introduction to Fourier Optics (The McGraw-HillCompanies, Inc., 1996).

[13] Principles of Optics, edited by M. Born, E. Wolf (Cambridge University, 2001).

[14] R. D. Guenther, Modern Optics (John Wiley \& Sons, 1990).

[15] R. J. Noll, J. Opt. Soc. Am. 66, 207 (1976); https: //doi.org/10.1364/JOSA.66.000207.

[16] Adaptive Optics for Vision Science, edited by J. Porter, H. M. Queener, J. E. Lin, K. Thorn, A. Awwal (John Wiley \& Sons, Ltd, 2006).

[17] R. W. Gray, C. Dunn, K. P. Thompson, J. P. Rolland, Opt. Express 20, 16436 (2012); https://doi.org/10. 1364/OE. 20.016436.

[18] V. Lakshminarayanan, A. Fleck, J. Mod. Opt. 58, 1678 (2011); https://doi.org/10.1080/09500340. 2011.633763.

[19] L. N. Thibos, X. Hong, A. Bradley, R. A. Applegate, J. Vision 4(4), 329 (2004); https://doi.org/10.1167/ 4.4.9.

[20] A. V. Kovalenko, V. N. Kurashov, Radioelectron. Commun. Syst. 47(7), 54 (2004); http://radioelektronika.org/article/view/ S0735272704070118.

[21] M. Siemons, C. N. Hulleman, R. Ø. Thorsen, C. S. Smith, S. Stallinga, Opt. Express 26, 8397 (2018); https:// doi.org/10.1364/OE.26.008397.

[22] C. Neipp, I. Pascual, A. Beléndez, Appl. Opt. 41, 4092 
(2002); https://doi.org/10.1364/A0.41.004092.

[23] A. A. Goloborodko, M. M. Kotov, V. N. Kurashov, D. V. Podanchuk, Opt. Eng. 55, 121710 (2016); https: //doi.org/10.1117/1.0E.55.12.121710.

[24] A. A. Goloborodko, DOE generator v 2.0 (2017); https: //www.researchgate.net/publication/312472533.

[25] A. V. Kuzmenko, P. V. Yezhov, Appl. Opt. 46, 7392 (2007); https://doi.org/10.1364/A0.46.007392.

[26] P. V. Yezhov, A. V. Kuzmenko, J.-T. Kim, T. N. Smirnova, Opt. Express 20, 29854 (2012); https://doi.org/ 10.1364/OE. 20.029854 .
[27] S. Thomas et al., Mon. Not. R. Astron. Soc. 371, 323 (2006); https://doi.org/10.1111/j.1365-2966.2006. 10661.x.

[28] Y. Zhang, W. Xu, S. Chen, J. Ge, F. Wan, Opt. Commun. 371, 76 (2016); https://doi.org/10.1016/ j.optcom.2016.03.053.

[29] D. V. Podanchuk et al., Appl. Opt. 55, B150 (2016); https://doi.org/10.1364/A0.55.00B150.

[30] L. Seifert, J. Liesener, H. Tiziani, Opt. Commun. 216, 313 (2003); https://doi.org/10.1016/S0030-4018(02) 02351-9.

\title{
ВПЛИВ ШУМУ ТА РОЗМІРУ ТОЧКИ НА ХВИЛЬОВИЙ ФРОНТ, ЗГЕНЕРОВАНИЙ АМПЛІТУДНИМИ ГОЛОГРАМАМИ
}

\author{
А. О. Голобородько ${ }^{1,2}$ \\ ${ }^{1}$ ТОВ OpenSoft, вул. Чорноморсъка, 1, оф. 301, Київ, Украӥна, \\ ${ }^{2}$ Київсъкий Національний університет імені Тараса Шевченка, \\ вул. Володимирсъка 64/13, Київ, 01601, Украӥна \\ e-mail: a.a.goloborodko@gmail.com
}

Для попередньої компенсації спотворень оптичного хвильового фронту розроблено різноманітні пристрої та методики адаптивної оптики, а статичні виправлення аберацій продемонстровано в різних лабораторіях із використанням як гнучких дзеркал, так і рідкокристалічних просторових модуляторів. При цьому достатньо перспективним є застосування голографічних елементів в адаптивних оптичних системах $\mathrm{i}$ приладах. Головною перевагою таких елементів є їхня простота виготовлення й точність, оскільки ці елементи працюють на пропускання, а не на відбивання, як гнучкі дзеркала. Тому в цій статті теоретично та експериментально досліджено можливості генерації та відновлення хвильового фронту амплітудними голограмами. Голограми можуть бути розраховані за допомогою комп'ютерної програми як 2D-масиву амплітудних спотворень і мати той же набір аберацій, що вводяться оптичним каналом або протилежним для їх компенсації. А вивчення ефективних алґоритмів, що можуть використовуватися для оцінки та корекції аберацій різних оптичних систем, є перспективним з погляду проблем адаптивної оптики. Показано, що розроблені та виготовлені амплітудні дифракційні оптичні елементи є найпростішим способом корекції аберацій оптичних систем. У роботі отримані хвильові фронти, що утворені зґенерованими голограмами. Установлено, що похибки відновлення хвильових фронтів, які отримані на прикладі перших 12 аберацій Церніке, не перевищують $5 \%$ та можуть бути зменшені через поліпшення процесу виготовлення голограм. Досліджено вплив амплітудних шумів на якість зображення в сенсорі Шека-Гартмана та встановлено, що виготовлені голограми i, відповідно, згенеровані ними хвильові фронти є достатньо стійкими до амплітудних шумів з відносною інтенсивністю $30 \%$. Вплив таких шумів можна зменшити введенням системи фільтрації в системі переносу після голограми. Експериментально досліджено вплив розміру елементарної точки (пікселя) на гартманограми та відновлення хвильових фронтів. Показано, що похибка відновлення хвильового фронту, згенерованого амплітудним дифракційним елементом з розміром точки менше 50 мкм, лежить у межах $5 \%$ і використання оптичної системи переносу зі зменшенням променя, яка може вводити додаткові аберації, не є необхідним. 